\title{
Benefit sharing in the value chain of Indian mackerel Rastrelliger kanagurta in Karnataka: A policy perspective
}

\author{
N. ASWATHY, K. M. RAJESH, DIVYA VISWAMBHARAN AND PRATIBHA ROHIT \\ *ICAR-Central Marine Fisheries Research Institute, Ernakulam North P. O., Kochi - 682 018, Kerala, India \\ Mangalore Research Centre of ICAR-Central Marine Fisheries Research Institute, Mangalore - 575001 \\ Karnataka, India \\ e-mail: aswathy.icar@gmail.com
}

\begin{abstract}
Harvest and post-harvest activities in a multispecies multifleet unregulated marine fishery is highly complex involving a large number of intermediaries. The real economic benefits from fishing are often skewed in the hands of a few intermediaries in the value chain. Equitable distribution of benefits is an essential component for ensuring sustainable exploitation and management in the context of ecosystem based management of marine fisheries. The present study analysed the market linkages and benefit sharing by different stakeholders in the value chain of Indian mackerel in Karnataka, south-west coast of India. Results of the study indicated that in terms of individual benefits, export processing and canning sectors in Karnataka grabbed a significant share in the Indian mackerel value chain and suggests a revisit into the policy on export incentives for Indian mackerel, in order to ensure equitable distribution of benefits among the stakeholders as well as to protect the interests of domestic consumers.
\end{abstract}

Keywords: Benefit sharing, Indian mackerel, Policy perspective, Value chain

\section{Introduction}

The Indian mackerel Rastrelliger kanagurta is a very important species of commercial fisheries in the South and South-east Asian countries (Devaraj et al., 1997; Al-Mahdawi and Mehanna, 2010; Jayabalan et al., 2014). It is the national fish of India and a significant contributor to the marine fish landings of the country. Indian mackerels are rich source of omega-3 fatty acids and other essential nutrients and regular consumption of the fish are reported to alleviate diseases/disorders related to malnutrition and ageing (Aneesh et al., 2012). Even though the production of mackerel has showed an increasing trend, there has been a consistent rise in the price of mackerel in the domestic markets indicating a supply-demand gap (Aswathy and Narayankumar, 2014). The average price of Indian mackerel in the country increased from ₹ 46 per kg in 2010 to ₹ 110 per $\mathrm{kg}$ in 2016 at landing centre level wher as at retail level, the price increased from ₹70 per $\mathrm{kg}$ to ₹200 per kg during the same period (Sathiadhas et al., 2012; CMFRI, 2017). The total mackerel landings in the country increased from 2.05 lakh t in 1994 to 2.67 lakh t in 2010 where as the exports (in terms of percentage to total landings) increased from a mere 0.30 to $26 \%$ during the same period (Aswathy and Narayankumar, 2014). In 2016, of the total 2.49 lakh $\mathrm{t}$ of mackerel landed, 1.29 lakh $\mathrm{t}$ (www.zauba.com) were exported reiterating the fact that mackerel is an important part of our marine fish exports and a large portion of the mackerel landings is taken up by exporters. Karnataka, Kerala, Goa, Maharashtra, Andhra Pradesh and Tamil Nadu were the major contributors to the landings of Indian mackerel in 2016 (CMFRI, 2017; Somy Kuriakose and Sijo Paul, 2017).

Equitable distribution of benefits is an essential component for sustainable exploitation and management of marine fisheries, especially in the context of ecosystem based management. The FAO small scale fisheries (SSF) guidelines also support equitable distribution of benefits derived from responsible fisheries management with particular emphasis on rewarding small scale fishers and fish workers (FAO, 2015). Since the 'demand creates supply principle' holds good in the case of open access common property resources, the increased market demand for marine resource will have serious repercussions on the sustainability of the resource. In this context, an analysis of the market linkages and benefit shares in the value chain of the Indian mackerel was conducted in the state of Karnataka to assess the benefit sharing in the value chain and to suggest policies for equitable distribution of benefits.

The State of Karnataka with a coastline of $300 \mathrm{~km}$ has 96 fish landing centres including five major fishing harbours (Mohammed et al., 1998). The marine fish production in the state reached a record 5.29 lakh $\mathrm{t}$ in 2016 and the Indian mackerel formed $22 \%$ of the catch. Indian 
mackerel is mostly landed by the mechanised purse seiners and trawlers in Karnataka (CMFRI, 2017). Mangalore, Malpe and Karwar fishing harbours together contribute $60 \%$ of the total mackerel catch in Karnataka. Hence these three fishing harbours were selected for the study.

\section{Materials and methods}

Mangalore, Malpe and Karwar respectively from Dakshina Kannada, Udupi and Uttara Kannada coastal districts in Karnataka were selected for the present study. The marketing channels for Indian mackerels in the selected landing centres were identified. Details of boat owners, auctioneers, interstate traders, quantity of fish handled by them, disposal/utilisation pattern (in local markets, interstate transfer, industrial utilisation and exports) as well as cost involved in washing, icing, packing and transport of fish were collected from these selected centres. The information pertaining to the price of fish, cost involved in washing, icing, packing, loading, unloading and transport, market tax, commission charges and profit margin, were collected from different marketing channels. The information collected from the processing plants and canning plants included: quantity purchased, purchase price, days of operation in a year, quantity processed per day, cost of production and prices of final products, number of workers in the firm and labour cost. The information from fish landing centres, fish markets and processing centres were collected using customised schedules.

Secondary data on species-wise landing data of marine fishes for the year 2016 was obtained from National Marine Fisheries Data Centre (NMFDC) of ICAR-Central Marine Fisheries Research Institute (ICAR-CMFRI). Kochi. The quantum of catch traded by different stakeholders was estimated based on landings data and catch share by various intermediaries. Primary data on prices of fish at landing centres, wholesale and retail levels were collected at fortnightly intervels to calculate the benefit shares of various traders. Data on costs and revenues of different fishing units were collected for calculating the fishing costs per $\mathrm{kg}$ of fish.

The samples were selected randomly from each category in such away as to cover more than $15 \%$ of the total stakeholders in the case of wholesale traders, retail vendors and interstate traders. More than $50 \%$ of the existing units were sampled in the case of fish cutting sheds, processing units and canning plants.

The net benefit earned for each category of stakeholders was worked out as follows:

Net benefit (profit) earned by the traders $=($ Total quantity traded $\mathrm{x}$ Average selling price per $\mathrm{kg}$ ) - (Cost of fish purchase + Marketing costs)
The cost of raw material/fish purchase cost and marketing/processing costs were deducted from the final product value to get the net benefit earned by each of the stakeholder. From the total profits (net benefit) earned by various stakeholders, the benefit shares were calculated for each category.

The net profit for processors was obtained by subtracting the purchase price, marketing and processing costs from the gross value realised. Primary data on all fixed and variable cost components including initial investment, labour costs comprising salaries of managers, electricity charges, transportation, packing and other miscellaneous expenses, as well as quantity of mackerel processed by each firm per year were collected for calculating the processing cost per $\mathrm{kg}$ in the case of processing units, canning units and cutting sheds. The cost of fish purchase was calculated by multiplying the quantity traded with average purchase price per kg. Similarly, the marketing cost was calculated by multiplying the quantity traded with average marketing cost per $\mathrm{kg}$ and processing cost was calculated by multiplying the quantity traded with average processing cost per $\mathrm{kg}$. The profit earned by processors was worked out as:

Profit earned by processors $=($ Total quantity traded $\mathrm{x}$ Average selling price per $\mathrm{kg})$ - (Cost of fish purchase + Marketing costs + Processing costs).

The profit earned by the boat owner was calculated as:

Profit earned by the boat owner $=$ Total value of fish (mackerel) realised by the boat owners at landing centers - (Fishing costs + Auction charges).

The fishing cost per $\mathrm{kg}$ of fish for each category of fishing unit was calculated based on the primary data on operational and capital costs and quantum of fish landed per fishing trip. The average fishing cost per $\mathrm{kg}$ of mackerel was then calculated based on the proportion of mackerel landed by each category of fishing unit.

The fishing cost included operational and fixed costs. Operational cost comprised costs of fuel, labour (crew share and bata), ice, repair and maintenance, food for the crew and other miscellaneous expenses. Fixed costs included depreciation on craft, engine, gears and accessories as well as interest on fixed capital.

The benefit share for the individual stakeholder in each sector was calculated by taking into consideration, the total number of stakeholders in the particular sector. Based on this, sector-wise benefit shares were calculated:

Benefit shares by individual stakeholder $=$ Total benefit earned by the category / No. of individuals in the category. 


\section{Results and discussion}

\section{Market linkages and utilization pattern of Indian mackerel in Karnataka}

The fish market linkages in Karnataka are unorganised and unregulated and in most cases the landed fishes pass through different intermediaries such as auctioneers, interstate traders, wholesalers, retailers, cycle/scooter/ autorickshaw vendors, fish cutting centres and fish processing plants, before reaching the final consumers. The market linkages in the value chain of Indian mackerel in the selected fishing harbours showed only slight variations (Fig. 1). Of the total quantity of mackerel landed in Mangalore and Malpe fishing harbours, 40\% was taken by the export processing sector, $29 \%$ by local retailers and $15 \%$ by interstate traders, whereas in Karwar fishing harbour, $37 \%$ was taken for domestic consumption within the state, $46 \%$ by interstate traders and $17 \%$ goes for exports.

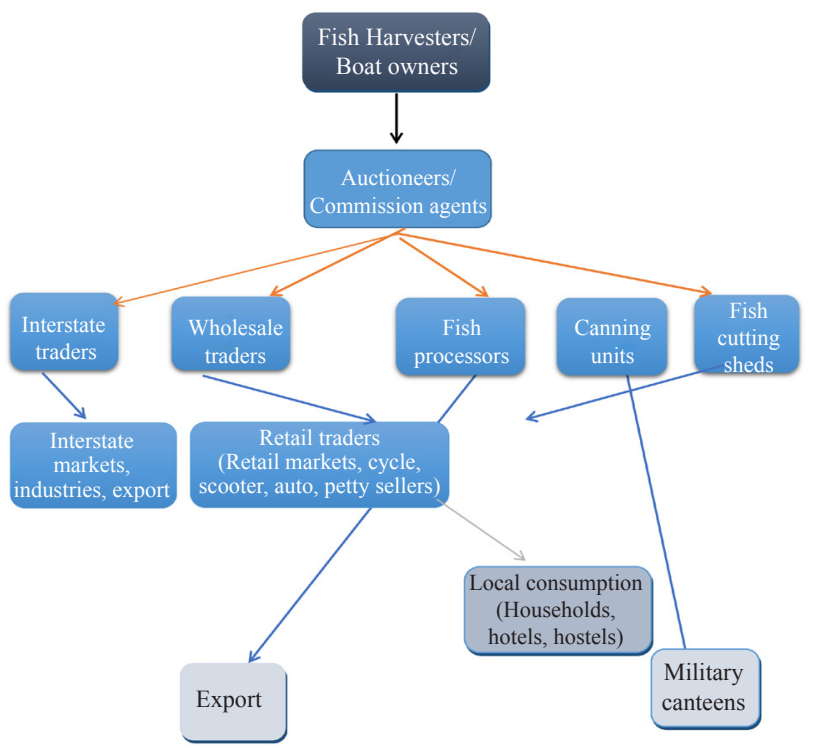

Fig. 1. Utilisation pattern of Indian mackerel landed in Karnataka

Benefit sharing in the Indian mackerel value chain in Karnataka

The estimated landings of Indian mackerel at the major landing centres (Mangalore, Malpe and Karwar) in Karnataka during 2016 was 53,819 t and the gross value realised at the final product level was ₹9,22 crores (Table 1).

The net profit realised by each category of stakeholder was calculated by deducting the marketing and processing costs as well as fish purchase costs from the value of the final product (sales revenue). Marketing and processing costs were highest for the processing plants at ₹4599 lakhs followed by interstate traders at ₹ 1170 lakhs (Table 2 ). Even though the fish procurement costs and marketing costs were higher for the processors, the net profit realised was higher due to the volume of trade and high profit realised per $\mathrm{kg}$ of fish. The boat owners realised an aggregate value of ₹65,330 lakhs from the sale of mackerels and the fishing costs along with auction charges amounted to ₹23, 819 lakhs from all the selected harbours.

Sector-wise share of net benefits indicated that the boat owners received the maximum $(65 \%)$ share of the aggregate profits realised followed by processing plants $(14.61 \%)$ and local traders (12.27\%) (Table 3). In terms of annual net benefits per individual unit, processing units received the highest share (₹4.66 crores) followed by canning units (₹2.67 crores). Among the fishing units, purse seiners earned the highest net benefits of ₹71.10 lakhs (Table 4). Even though the boat owners received the highest aggregate benefits in the mackerel value chain, the benefit to individual fishers was less due to the large number of boats operated.

The study brings to light the fact that the export processing sector in Karnataka grabs huge economic gains in the Indian mackerel value chain. The mackerel from Karnataka are usually exported as frozen (whole round) and Individual quick frozen (IQF) forms. The profit realised per $\mathrm{kg}$ of fish ranged from ₹45-50 per $\mathrm{kg}$ in the

Table 1. Catch and value of Indian mackerels landed in the selected fishing harbours

\begin{tabular}{lll}
\hline Particulars & Catch $(\mathrm{t})$ & Final product value (₹lakhs) \\
\hline Mangalore & 26228 & 43426 \\
Malpe & 23367 & 41575 \\
Karwar & 4224 & 7291 \\
Total & 53819 & 92292 \\
\hline
\end{tabular}

Source:NMFDC, ICAR-CMFRI, Kochi (2017)

Table 2. Aggregate sales revenue and costs for different stakeholders in the selected fishing harbours (₹lakhs)

\begin{tabular}{lllll}
\hline Particulars & Sales revenue (A) & Cost of fish purchase (B) & Marketing and processing costs (C) & Net profit A-(B+C) \\
\hline Wholesalers & 20136 & 17598 & 719 & 1819 \\
Retailers & 19543 & 15185 & 328 & 4030 \\
Two wheelers & 3600 & 2686 & 63 & 851 \\
Auto vendors & 4246 & 3242 & 71 & 933 \\
Head loaders & 961 & 745 & 17 & 199 \\
Interstate traders & 16966 & 11434 & 1170 & 4362 \\
Processing plants & 39057 & 25136 & 4599 & 9322 \\
Fish cutting sheds & 9663 & 9103 & 298 & 262 \\
Canning plants & 1339 & 607 & 198 & 534 \\
\hline
\end{tabular}


Table 3. Benefit shares of different stakeholders in Indian mackerel value chain in Karnataka (values in ₹lakhs)

\begin{tabular}{llllll}
\hline \multirow{2}{*}{ Particulars } & \multicolumn{3}{c}{ Net profit } & Profit share (\%) \\
\cline { 2 - 5 } & Mangalore & Malpe & Karwar & Total & \\
\hline Boat owners & 19406 & 18458 & 3647 & 41511 & 65.04 \\
Local traders & 3994 & 3220 & 618 & 7832 & 12.27 \\
Interstate traders & 1967 & 1577 & 818 & 4362 & 6.83 \\
Processing plants & 5003 & 3990 & 329 & 9322 & 14.61 \\
Others & 446 & 350 & - & 796 & 1.25 \\
\hline Total & 30816 & 27595 & 5412 & 63823 & 100.00 \\
\hline
\end{tabular}

Table 4. Benefit shares by individual stakeholders

\begin{tabular}{llll}
\hline Particulars & Total net profit (₹lakhs) & No. of stakeholders & Net profit per Unit (₹lakhs) \\
\hline Wholesalers & 1819 & 405 & 4.49 \\
Retailers & 4030 & 760 & 5.30 \\
Two wheelers & 851 & 200 & 4.26 \\
Auto vendors & 933 & 440 & 2.12 \\
Head loaders & 199 & 170 & 1.17 \\
Interstate traders & 4362 & 160 & 27.26 \\
Processing plants & 9322 & 20 & 466.10 \\
Fish cutting sheds & 262 & 52 & 5.05 \\
Canning plants & 534 & 2 & 266.76 \\
Trawl owners & 18349 & 2879 & 6.37 \\
Purse seine owners & 17774 & 250 & 71.10 \\
Gillnet owners & 4725 & 1615 & 2.93 \\
Others & 663 & 3546 & 0.19 \\
\hline Total & 63823 & 10499 & 863.1 \\
\hline
\end{tabular}

case of processing units and ₹ $117-122$ per keg for canning units. The huge profits realised by the export processing sector might have contributed to the increase in exports and consequent price rise in the domestic markets. The retail price of mackerels increased from ₹82 per $\mathrm{kg}$ in 2010 to ₹ 184 per $\mathrm{kg}$ in 2016 (Sathiadhas et al., 2012; CMFRI, 2017). Viswanatha et al. (2015) reported on the proliferation of processing and canning units in Karnataka during 1970-2009 period. The analysis indicated that total marine fish disposed to freezing plants increased from $3,344 \mathrm{t}(5 \%)$ to $12,708 \mathrm{t}(10 \%)$ during 1970 to 2009 period which shows the rise in the number of freezing plants in the state.

The results of the present analysis showed the skewness in the domestic marine fish marketing system in India as already reported by Sathiadhas et al. (2012). Producers and consumers bear the brunt of monopoly of big traders dominating at the point of first sales. Further, growing export of finfish has created scarcity for premium fish varieties in the domestic marketing system. The inadequate infrastructure available for the domestic marketing coupled with erratic catches and seasonal distribution make the processors and exporters to reap huge economic gains from bulk landings (Sathiadhas et al., 2012). India had exported $11,34,948 \mathrm{t}$ of seafood worth US\$ 5.78 billion during 2016-17 in which frozen fish accounted $26.15 \%$ (www.mpeda.com)

The new economic reforms with the Indo-ASEAN free trade agreement also favoured exports of Indian mackerel from India to South-east Asian countries with less stringent trade regulations (Aswathy and Narayanakumar, 2014). Further, the export incentives for Indian mackerel introduced from 2015 also might have contributed to increased export of mackerel from India. Government of India introduced the export promotion scheme, 'Merchandise Exports from India Scheme (MEIS)' through the Foreign Trade Policy (FTP) w.e.f. 1 April 2015. Under the MEIS scheme, Indian mackerel R. Kanagurta exported under the Indian Trade Clarification based on Harmonised System of Coding (ITC HS) 2012 / 2017 is eligible for MEIS incentive at the rate of 5\% for exports during the period 01 April 2015 to 31 October 2017 ) and $7 \%$ for exports during the period 01 November 2017 to 30 June 2018) (PIB, 2016; GOI, 2018). Rewards under MEIS are payable by way of the MEIS duty credit scrip which can be used for payment of a number of duties/ 
taxes including customs / excise duty / service tax. This has provided much flexibility to exporters and favoured the exports of Indian mackerel from the country. However considering the huge domestic demand for Indian mackerel in the country and low comparative advantage for finfish exports, it is imperative to revisit the policy on export incentives for Indian mackerel. Nikhitha et al. (2009) studied comparative advantage of finfish export from India for the period 2001 to 2005 and reported that export of finfish from India has been rising over the years and finfish export had no comparative advantage among the total marine products export. The study also suggested reviewing the policy of finfish export, with a shift in emphasis to export of only high value finfish and value added low value finfish. Shyam (2016) also reported that the increase in export earnings from low value fishes like oilsardine and mackerel from India are due to increase in the quantity exported and not due to increase in unit value realised at export market.

Increasing export trends naturally increases the fishing pressure on mackerel and at times leads to targeted fishing, therefore adequate caution has to be taken to ensure its sustainability. Considering the huge demand and rising price of mackerel in the domestic markets, domestic marketing needs to be strengthened for efficient distribution of the catch landed so as to avoid distress sales during glut and to prevent spoilage losses.

Analysis of the market linkages and benefit sharing in the value chain of Indian mackerel in Karnataka indicated that there is inequitable distribution of benefits among the various stakeholders. The processing and canning sectors grab a significant share of economic benefits. In addition, the export incentives along with free trade agreements also favour the exports of Indian mackerel. The increased export demand poses a threat to sustainability of resources by way of overexploitation driven by market demand and affects availability for domestic consumers. The Indian mackerel once considered an easily available protein source for the domestic consumers has now become a high value food item during the recent past. Hence there is need to revisit the policy on export incentives for mackerel to protect the interests of domestic consumers and to ensure equitable distribution of benefits to different stakeholders in the value chain.

\section{Acknowledgements}

The financial assistance extended by Karnataka Biodiversity Board to carry out this work is gratefully acknowledged. Thanks are due to the Director, ICARCMFRI, Kochi for the support and facilities provided.

\section{References}

Al-Mahdawi, G. J. and Mehanna, S. F. 2010. Stock assessment of the Indian mackerel Rastrelliger kanagurta (Cuvier, 1816) in the Yemeni Coast of Red Sea, Al-Hodeidah region. In: Proceedings of the $3^{\text {rd }}$ Global Fisheries and Aquaculture Research Conference, 29 November - 1 December, 2010, Cairo, Egypt, p. 220-230.

Aneesh, P. A., Jones Varkey, Anandan, R., Mathew, S., Asha, K. K., Lakshmanan, P. T., Sankar T. V. and Mohanty, B. P. 2012. Proximate composition, amino acid and fatty acid profiles of commerson's anchovy (Stolephorus commersonii) and Indian mackerel (Rastrelliger kanagurta). Biochem. Cell. Arch., 12(2): 371-376.

Aswathy, N. and Narayanakumar, R. 2014. Upsurge in exports and price rise of mackerels in the retail markets of Kerala. Mar. Fish. Infor. Serv., T\&E Ser., 219: 16-18.

Aswathy, N., Shyam, S. Salim, Vipinkumar, V. P. and Narayanakumar, R. 2017. Price behaviour, marketing channels and efficiency of marine fish marketing in Karnataka. Mar. Fish. Infor. Serv., T\&E Ser., 232: 15-17.

CMFRI 2017. Marine fish landings in India 2016. Technical Report, CMFRI Booklet No.10/2018, ICAR-Central Marine Fisheries Research Institute, Kochi, 10 pp.

Devaraj, M., Kurup, K. N., Pillai, N. G. K., Balan, K., Vivekanandan, E. and Sathiadhas, R. 1997. Status, prospects and management of small pelagic fisheries in India. In: Devaraj, M. and Martosubroto, P. (Eds.), Proceeding of the $1^{\text {st }}$ Session of the APFIC Working Party on Marine Fisheries. 13-16 May 1997, Bangkok, Thailand, $445 \mathrm{pp}$.

FAO 2015. Voluntary guidelines for securing sustainable smallscale fisheries in the context of food security and poverty eradication. Food and Agriculture Organisation of the United Nations, Rome, Italy, 18 pp.

GOI 2018. Public Notice No. 13/2015-2020. Ministry of Commerce and Industry, Department of Commerce Directorate General of Foreign Trade, Government of India, New Delhi.

Jayabalan, N., Zaki, S., Al-Kiyumi, F., Al-Khadrusi, L. and Al-Habsi, S. 2014. Age, growth and stock assessment of the Indian mackerel Rastrelliger kanagurta (Cuvier, 1817) along the Sohar Coast of Oman. Indian J. Fish., 61(1): 1-6.

Mohamed, K. S., Muthiah, C., Zacharia, P. U., Sukumaran, K. K., Prathibha Rohit and Krishnakumar, P. K. 1998. Marine Fisheries of Karnataka State, India. Naga, ICLARM Qly, 21(2): 10-15.

Nikita Gopal, Jeyanthi, P., Geethalakshmi, V. and Unnithan, G. R. 2009. Indian finfish exports - An analysis of export performance and revealed comparative advantage. Agric. Econ. Res. Rev., 22: 291-297.

PIB 2016. Merchandise Export from India Scheme, Press Information Bureau, Ministry of Commerce and Industry, Government of India. 
Sathiadhas, R. and Narayanakumar, R. 1994. Price policy and fish marketing system in India. J. Biol. Educ., 11(4): 225-241.

Sathiadhas, R., Narayanakumar, R. and Aswathy, N. 2012. Marine fish marketing in India. ICAR-Central Marine Fisheries Research Institute, Kochi, Kerala, India, 276 pp.

Shyam S. Salim 2016. Food and beverage news, 1-15 August 2016.
Somy Kuriakose and Sijo Paul 2017. Marine fish landings in Karnataka during 2016 - An overview, Mar. Fish. Infor. Serv., T\&E Ser, 233: 11-13.

Viswanatha, B. S., Senthiladeban, R., Rajakumar, M. and AmaliInfantina, J. 2015. An overview of marine fisheries infrastructure and fish utilisation pattern in Karnataka, India, Int. J. Fish. Aquat. Stud., 2(4): 233-238. 